\title{
13. Life under Decree No. 29 of 2010: The Fiji Media Development Decree
}

\section{ABSIRACI}

This article examines the domestic and regional impact of a punitive media law introduced in Fiji in June. Decree No. 29 of 2010, the Media Industry Development Decree, is the first of its kind in the South Pacific. It brings to an end the tradition of media self-regulation, one of the hallmarks of a free media. All Fiji governments since independence have tried to introduce tougher media laws. The Bainimarama government, which took power in a coup in December 2006, has succeeded where others failed. Its media decree prescribes hefty fines and jail terms for journalists who fall foul of the law. Given the precedent in Fiji, it is unlikely that a future government will move to change this law, which could become a permanent fixture in the country. This article looks at the impact of the law in Fiji and raises the possibility of copycat laws in other island countries where governments distrust media. The article also questions the applicability of conventional journalistic approaches, which place a premium on conflict as a news element, in politically fragile island countries.

Keywords: bias, censorship, self-regulation, media law, media ethics, media regulation, objectivity, race relations

\section{SHAILENDRA SINGH}

University of the South Pacific, Fiji

7 HE DATE 28 June 2010 will go down as a fateful day in Fiji's history. New media laws enacted on this date have changed the way

journalism has been practised in the country. Whether for better or worse depends on whom one speaks to. Supporters of the Media Industry Development Decree feel that punitive laws prescribing fines and jail terms are needed to curb media excesses. They believe that Western media models 
do not sit easily in democratically fragile, multiethnic societies such as Fiji, which has experienced four coups in 20 years since 1987. The Fiji media, they argue, put itself at risk through unrestrained, aggressive coverage of sensitive racial and political issues. Opponents of the law, on the other hand, see it as a naked attempt to control the media. They believe that a free press is a strength not a weakness. They liken the new law to a stake driven through the heart of freedom of expression and predict dire consequences for the nation. One clause in the decree, for instance, stipulates that all media in Fiji should be 90 percent locally owned. This will force The Fiji Times, whollyowned by News Limited, to sell up or shut down. The Times celebrated 141 years in Fiji in September this year. Many readers are left lamenting the possible demise of this iconic, if sometimes controversial, newspaper.

\section{Emergency Regulations}

The media decree was introduced by Prime Minister Frank Bainimarama's government. It brings to an end the tradition of self-regulation, one of the hallmarks of a free media. Military Commander Bainimarama had taken power in the December 2006 coup. For 15 months prior to the decree's promulgation, the country had its first taste of what it was like living under prolonged media censorship. Government introduced 'Emergency Regulations' in April 2009, with censors sent into newsrooms to clear copy for publication. Overnight, news that was critical of the government dried up. Government opponents in the trade unions, academia and politics were effectively silenced, although a few received some foreign media coverage. It was a new, uncanny experience for Fiji which, apart from a brief period after the coups of 1987, has always had a free media on a par with Australia and New Zealand. There were occasional rants or threats by politicians to shut down newspapers. But such threats were never carried out and journalists did their work virtually unhindered (We are global: From Fiji, a journalist's stand on censors, bloggers and future of free press expression, 2010).

\section{Copycat media laws}

Fiji's media decree could inspire copycat laws in a region where some governments are suspicious of the press and habitually threaten tougher media laws. Papua New Guinean Prime Minister Sir Michael Somare offered tacit support for the media crackdown in Fiji (PNG prime minister offers 
Bainimarama tacit support, 2010). Somare, a former journalist, is a longstanding critic of both domestic and international media coverage of Papua New Guinea. In 2008, when questioned on his stance on the deportation of two of Fiji's newspaper publishers, Somare warned PNG reporters to expect the consequences of what they report. He said: 'You are very lucky I have not deported anyone of you yet, for writing something contrary' (Somare Warns PNG Media, 2008).

Tonga, another country whose leaders have had strained relations with the media, is considering adopting a more restrictive media law (Tonga's Information Minister moves to clamp down on Island's newspapers, 2010). Criticism of Tonga's royal family and nobles, who dominate the island kingdom, is held to be contrary to Tongan culture. The media, however, has ignored etiquette and exposed many financial scandals over the years. This has not endeared journalists with Tongan authorities. Island governments habitually accuse media of bias, inaccurate reporting and other ethical breaches. Sometimes the complaints are a retaliatory tactic against embarrassing media revelations of government wrongdoing. At other times such complaints are genuine and cannot be easily dismissed as a case of shooting the messenger. Media loses public support and plays into the hands of autocratic governments when it consistently makes mistakes and breaches ethics. It does not do itself any favours when it takes the high moral ground, acts as if it is infallible, and does not address its weaknesses.

In politically or racially tense situations, an overly confrontational media gives governments reason (or excuse) to tighten laws. After a coup, the situation is often unpredictable. There is more paranoia than usual about the media. Those in power impose censorship to control news in order to prevent, among other things, 'inflammatory reporting', as in Fiji. A report about Fiji that appeared in The Australian is a case in point. It cited an unnamed Australian foreign affairs official saying, 'the people may have no choice but to stand up to him (Bainimarama) and his thugs' (Perfect one day, brutal the next, 2010). Bainimarama's reaction to the report was predictable:

This statement is inciting the people of Fiji to rise against my government and promoting further unrest ... on the one hand they say they are concerned about the welfare of the people of Fiji, whilst on the other they are inciting and promoting unrest in Fiji (Hands off, Fiji's leader tells Australia, 2010) 
Many in Fiji would consider the anonymous Australian foreign affairs official's statement as dangerous. Much as Australia and New Zealand dislike the Bainimarama administration, and however keen they are to see democracy restored, a rebellion is the last thing Fiji needs. Citizens would only be exposed to more violence and suffering. In coup situations unruly media is not just a danger to the public, but an excuse for the government to impose draconian laws.

\section{Conventional journalism in conflict-prone countries}

Recent developments in Fiji give rise to questions about the applicability of conventional styles of journalism in conflict-prone countries. Rooney, Papoutsaki and Pamba are critical of what they describe as the blind adherence to, and acceptance of, Western style reporting. They assert that this style cannot be transplanted into fragile Pacific societies with the assumption that they will serve the same purpose, meet the same objectives and be absorbed by the public in the same way (Rooney, Papoutsaki \& Pamba, 2004). While traditional news reporting has demonstrable strengths in exposing corruption and keeping leaders accountable, there are perceived weaknesses in this model when applied in unstable multiethnic societies, especially given the emphasis placed on conflict as a key element of news (Singh, Prakash, 2008). Media in Fiji and the region have won plaudits for exposing corruption, but criticised for its reportage of conflicts. In Fiji, the media is paradoxically seen both as a champion of democracy and as a security threat. The same could be said of media in other conflict-prone island countries such as $\mathrm{Pa}$ pua New Guinea, the Solomon Islands and Tonga. Since independence, the Pacific has become increasingly volatile. But most journalists are still stuck in a mind-set of 1970s-style reporting inherited from the British and other European models. Hyping up and sensationalising conflict may not result in a coup or riots in well-entrenched democracies with homogenous societies. But it can have devastating effects in conflict-prone, multi-ethnic societies such as in Fiji. The report in The Australian, which suggested an uprising might be the only solution left for Fiji, is a case in point. Flippant remarks by people with little knowledge about or regard for the Fiji situation can be dangerous, especially when propagated by an ignorant or uncaring media. The propensity for unrest and violence in Fiji is often underestimated, even after four economically devastating coups and a deadly mutiny at the army 
barracks in September 2006. With Fiji, people need to be careful about what they wish for. Their wish may well come true. Media should not inflame situations to the point that public safety is compromised.

\section{'Pacific media approach'}

With the news scene getting faster, more complicated and more contentious, journalism in Fiji and the region faces new challenges and demands. Independent Tongan newspaper publisher Kalafi Moala, while critical of Fiji's new media laws, recently spoke about the need for a 'new Pacific media approach' rooted in Pacific values. Said Moala:

We need to let things that are important to us as Pacific people be the guide to the way we tell our stories - the events, the issues, the people of our various cultures. It is our stories that need to be told, in our way, in accordance with our cultural view of realities that is the Pacific life. (New media body to focus on keeping Pacific governments 'honest', 2010)

Moala, who now also publishes the government newspaper Tongan Chronicle, believes the way the Tongan press covered political conflicts in Tonga was partly to blame for the November 2006 pro-democracy march deteriorating into a deadly riot in the Tongan capital, Nuku'alofa. He contends that during debates about political reform, the media used inflammatory language and criticised key figures without giving them the opportunity to respond (Prominent Tonga newspaper publisher says unbalanced reporting helped ferment riot, 2007). Former Pacific Islands News Association president Monica Miller supports Moala's views about a Pacific Island media model:

Journalists need to do more than go after the main news stories and fill the bulletin. They have to go after stories that will impact on people's lives. (New media body to focus on keeping Pacific governments 'honest', 2010)

Many Pacific Island journalists work in democratically fragile, ethnically polarised societies. Such societies are more prone to conflict than societies with greater ethnic homogeneity. Media should be conscious about the environment it is operating in and show sensitivity in the handling of 
certain subjects, such as politics, ethnicity and religion. It needs to question established norms of reporting, be more open to new ideas, and explore new concepts rather than dismiss them out of hand. Conventional journalism places a high premium on conflict as an element of news. In the Pacific context, there should be a case for exploring journalism that is less adversarial, and more geared towards development. For instance, peace journalism is a dirty word in mainstream news media where objectivity and the 5ws and one $\mathrm{H}$ framework for writing stories - Who, What, When, Where, Why, and How_rule. But peace journalism is being tried in some parts of Asia, which has cultural similarities with the Pacific and which, as a developing region, faces similar challenges. In the more volatile parts of Africa, media is open to, and applying, different journalistic principles to suit the local conditions.

\section{Fiji's Media Industry Development Decree}

Bainimarama says his aim is to achieve a better Fiji by rooting out corruption, introducing a non-racial electoral system and creating equal opportunities for all races in Fiji (Statement by Commodore Voreqe Bainimarama, 2008; PM determined to transform Fiji, 2009). Media 'reforms' are an apparent part of the government's social re-engineering efforts. Fiji's Attorney-General Aiyaz Sayed-Khaiyum describes the media decree as a substantial progress in the laws relating to media. He believes it provides for proper accountability and transparency, introduces responsible reporting, and provides the public with more effective recourse for complaints (Commencement of the media industry development decree, 2010). Reporters Without Borders, on the other hand, labeled the decree 'deplorable' and a 'dangerous step backwards for press freedom and media development in Fiji. Fijian journalists risked jail at a time when the international trend is for press offences to be decriminalised' (Reporters Without Borders, 2010). The International Federation of Journalists said the decree would erase the right of journalists to report freely and fairly in the public interest (Fiji media decree entrenches regime's control, 2010)

\section{A 'normal' relationship}

In Fiji, relations between media and government have always been contentious. While credit for the media decree goes to the Bainimarama government, a succession of elected and unelected leaders since independence in 
1970 have tried to muzzle what they see as an errant press (Singh, 2008). Fiji's founding prime minister, the late Ratu Sir Kamisese Mara, had little patience with what he regarded as an impertinent media corps. Ratu Mara was a daunting presence at press conferences, and a steely gaze from him was enough to stop a question in its tracks.

Sitiveni Rabuka, who seized power as a third-ranking army colonel in 1987, saw the closure of the original Fiji Sun. Rabuka's government was beset by corruption allegations, including the biggest financial scandal in Fiji's history, the $\$ 372$ million collapse of the National Bank of Fiji. Members of his government often lashed out at journalists and threatened news companies with closure, although Rabuka was more tolerant. Labour Party leader Mahendra Chaudhry, who came to power as Fiji's first prime minister of Indian descent in 1999, had a tenuous relationship with the media, which he accused of being in cahoots with nationalists wanting to bring down his government. Citing low standards, bias and the ineffectiveness of the Fiji Media Council, Chaudhry threatened to establish a 'swift justice' media tribunal and legislation to curb a 'distorting' and 'lying' news media (Fiji's Chaudhry duels with news media, 1999). Before he could make good on his threat, Chaudhry was toppled in the 2000 George Speight coup. He had been in power for just a year.

\section{Defining moment for media freedom}

The 19 May 2000 coup was a defining moment for the media in Fiji. Taking advantage of a protest march organised by Fijian hardliners in Suva, Speight and a handful of renegade soldiers stormed Parliament and captured Chaudhry and his government. The ensuing hostage crisis lasted 52 days until Speight's gang was captured and jailed by military commander Bainimarama. While the coup provided journalists with a lot of copy, it also gave rise to an unprecedented level of public and academic scrutiny in the inner workings of the media. The Fiji media found itself under the spotlight like never before. Many research papers and commentaries were written on media coverage of the Chaudhry Government's one-year rule, its forced removal and the ensuing hostage drama. The Fiji media was forced to defend itself against allegations of inflammatory reporting that allegedly emboldened Fijian hardliners and created the conditions for the Speight coup, and against claims of skewed and biased reporting during the hostage crisis.

Months before he was ousted in the coup, Chaudhry launched an extra- 
ordinary attack on the Fiji media during an address at the launching of the Fiji Media Council's Code of Ethics and Practice in Suva. He said:

Since taking office, my government has had occasion to be extremely disgusted by the antics of some elements in the media who have used the medium of the newspaper and television to further their own personal agendas to discredit the government. (Chaudhry, 1999)

The media dismissed the Chaudhry allegations as a case of shooting the messenger (Media: payback time for Fiji's news critics, 1999). The Fiji Times, in a two-page editorial, described Chaudhry's speech as a 'rambling diatribe riddled with contradictions, half truths and untruths'. It accused Chaudhry of escalating his attacks on the media in an effort to create a climate in which the public would be softened up for his draconian legislation (Fiji Times, 1999).

Political commentator Sitiveni Ratuva (as cited in Robie, 2000) believes the media did not create the conditions for the ethno-nationalist upsurge, which was already there. But it provided nationalists with the 'legitimacy' to roll on. Robie (2000) points to an 'unusually close' relationship in the early weeks of the insurrection between the media and hostage-takers, while Gounder (2004) describes how in their desperation to interview Speight journalists (wittingly or unwittingly) became his pawns. Some journalists developed the 'Stockholm syndrome' in that they began to sympathise with the Speight 'cause', while others found it hard to remain professional because of the strong cultural ties with the supporters of Speight's coup (p. 140). The then Fiji Media Council chairman, Daryl Tarte (2004), believes Speight knew that the media was the best channel through which he could propagate his 'crazy logic', and used it to garner Fijian support. He projected a personality that had media appeal (Media Councils in an unstable political environment, 2004; also see numerous evaluations of coup media coverage-Field 2000, 2005; Moala 2001; Robie, 2000, 2001, 2004; Thaman 2001; Chaudhry 2001). Speight's skills with the media showed how 'prominence' and 'conflict', two conventional news values drilled into student and cadet journalists, can be exploited by reporters to publish headline news (in order to make a name, get a promotion) and by newsmakers (such as Speight) to capture the headlines. Robie (2001) observed such a 'symbiotic relationship' between the media and Speight.

While the media denied culpability and insisted that a blundering Chaudhry 
was to blame for his government's downfall, the paranoia had set in. Future governments, spooked by the events of 2000, intensified efforts to rein in the media. This was exemplified by the actions of the Laisenia Qarase government, which came in after Chaudhry's ouster in an interim caretaker capacity in 2001, before winning elections in 2003 and 2006. The Qarase government unveiled the draft 2003 Media Council of Fiji Bill. At an editors' forum in Suva later, the Attorney-General at the time, Qoriniasi Bale, explained the Bill by saying that the quality of reporting in Fiji was poor enough to cause damage to governments (Bale, 2003). The Bill was shelved following a fierce 'No Media Bill' campaign mounted by the media. But after winning a fresh mandate in 2006, the Qarase government hinted that the Bill would be reintroduced. Mired in corruption allegations, the Qarase government may have had other motives to silence the media. But it was toppled by the Bainimarama coup before it could act. It was left to the Bainimarama government to take care of unfinished business, which it has. Since independence, all Fiji governments, whether elected or unelected, have tried to control the media. It seems unlikely that a future government will change a law that gives it a hold over the media. With the sword of Damocles hanging over the Fiji media (see Robie, 2004b), it could be the end of a culture of robust reporting that kept governments in check.

\section{Complex society, challenging occupation}

It must be said that being a journalist is not easy in a country like Fiji. Australian National University historian Professor Brij Lal describes Fiji as 'a bit like Churchill's Russia: a riddle wrapped in a mystery inside an enigma' (The ups and downs of Fiji politics, 2007). A multi-ethnic nation of more than 945,000 people, Fiji was a British Crown colony for 96 years before independence in 1970. According to the 2007 census, indigenous Fijians make up 57.3 percent of the population. Ethnic Indians, descended mostly from imported laborers who worked on colonial sugar plantations, are now 37.6 per cent of the population. Their numbers are dropping, thanks to migration and low birth rates. Europeans, people of mixed race, Chinese and other Pacific Islanders make up the rest of the population.

Voting in Fiji has always been on racial lines, and Fiji's two major races vote for the two major political parties that they believe best represent their interests. During elections, politicians cynically play the race card and fuel 
ethnic tensions by cultivating and exploiting the suspicions and prejudices of their particular communities. The result is that both sides of the racial divide feel marginalised: indigenous Fijians economically, ethnic Indians politically. Each group blames the other for its problems (Singh, 2010). It is not easy being a journalist in a country where everyone has a grievance, and often, journalists are caught in the crossfire. Such is the situation in Fiji, all governments and political parties and their supporters feel they have been hard done by the media.

Because of their cultural and racial ties, journalists are susceptible to pressure from their respective communities. Analysing the 2000 coup coverage, former Daily Post editor Jale Moala (as cited in Robie, 2000) argued that local reporters 'confused by the heightened emotion at the time, the use of emotive language and the pleadings of the opposing forces', were drawn into different sides. This was true of both indigenous Fijian and Indo-Fijian reporters, said Moala.

\section{Playing by the new rules}

Under the Media Industry Development Decree, a one-member Media Tribunal appointed by the President and a six-member Media Industry Development Authority appointed by the information minister will regulate the news media (Media Industry Development Decree, 2010). Their role is to 'ensure that nothing is included in the content of any media service' which is:

- against public interest or order,

- against the national interest,

- $\quad$ against good taste or decency, or;

- creates communal discord

The various offences are punishable by fines of:

- up to $\$ 100,000$ for media organisations

- up to $\$ 25,000$ for publishers or editors, and;

- up to $\$ 1000$ for journalists or other employees of media organisations

Furthermore, the tribunal may order compensation of up to $\$ 100,000$ to be paid by media organisations to 'any person aggrieved or adversely affected' by media reports. The right of appeal against tribunal decisions is available 
where a penalty of $\$ 50,000$ or more has been ordered.The tribunal can also order media organisations and their employee to disclose sources. Refusal can result in a $\$ 10,000$ fine, or jail terms of up to two years, or both (Media Industry Development Decree, 2010).

\section{Media Council neutralised}

The media decree puts an end to self-regulation overseen by the Fiji Media Council. The Council, made up of media industry, government and public members, has not been abolished but made redundant. It is now looking at its future, with folding up an option under consideration. The code of ethics adopted by the decree is virtually the same as the Fiji Media Council Code of Ethics. But the power bestowed on the tribunal to make media organisations pay compensation of up to $\$ 100,000$ to persons adversely affected by inaccurate reporting is a major change. Previously, the Media Council dealt with complaints. If a complaint was upheld, the judgment was printed in full on the websites and print publications of the Council's affiliates. Even then, some people complained about the difficulty faced getting the media to retract inaccurate reports or to print an apology. Yet others considered the penalty of publishing media council judgments a mere slap on the wrist. Those who support the new provisions believe that it will uplift standards as well as ensure that complainants get fairly treated and receive adequate compensation. Opponents of the law say that it will open a Pandora's box. Media companies and the tribunal will be inundated with frivolous complaints. This will include complaints from opportunists attracted by the possibility of making money. Those who do not support the provision say that defamation, privacy and other media legislation currently in place offer adequate protection, recourse, and compensation to complainants. They caution about the unintended side effect of excessive legislation and punitive measures - a meek, ineffectual news media.

\section{The public interest conundrum}

Particularly troubling for journalists is the power bestowed on the authorities to 'ensure that nothing is included in the content of any media service which is against public interest or order, or national interest'. What is for or against the public interest can be a highly debatable issue. The government can have one view, the opposition another and the media an entirely different one. Some believe plurality of views is healthy for Fiji. Others 
believe Fiji needs a benevolent dictatorship. But the question remains: Will a newspaper be guilty of a crime if it were to carry a strident editorial opposed to the government's stand on an issue concerning the national interest? For instance, when the media published the names of defaulters in the National Bank of Fiji loans scandal in the 1990s, the Rabuka government accused it of acting against the national interest. The government's stand was understandable: prominent businesses and the politically well connected topped the list of those who had taken huge, unsecured loans from the state bank. The finance minister at the time, Berenado Vunibobo, seemed keen to wash government's hands of the affair, and get the media off its back. In 1995, Vunibobo dismissed the collapse of the NBF as 'water under the bridge' (Lal, 2010). This was wishful thinking. In 1996 the NBF's bad and doubtful debts were estimated at more than 8 percent of GDP-equivalent to a $\$ 10$ billion mistake had it been in New Zealand (Grynberg, Munro and White, 2002). The biggest financial scandal in Fiji's history eventually cost taxpayers $\$ 372$ million, according to the Fiji Reserve Bank Governor, Sada Reddy (Raising investment a challenge, 2010).

\section{Disclosure provision}

There is concern that the disclosure provision in the decree can be used by future governments to hide corruption. Non-compliance with this provision will attract fines of up to $\$ 10,000$, or jail terms of up to two years, or both. The decree does exempt media organisations from disclosing the identity of the sources of any news item relating to corruption or abuse of office by a public officer (Media industry development decree, 2010). Nevertheless, such a provision, it is argued, will kill off a fairly healthy whistle-blowing culture in Fiji. The cynical describe the disclosure provision as a 'shield law': not to shield whistleblowers, but to shield government corruption and misrule. While the Bainimarama government has set up the Fiji Independent Commission Against Corruption (FICAC) to investigate and prosecute cases of bribery, the new disclosure laws will discourage people from providing media with information. Even if insiders do pluck up the courage to provide confidential information in the public interest, the media will baulk at using it because of the possible penalties.

\section{Local shareholding clause}

A provision in the decree that requires all news media to have 90 percent 
local shareholding has snared The Fiji Times, wholly owned by Rupert Murdoch's News Limited. The Fiji Times was given three months from the date of the decree's promulgation to sell up, or close down. ${ }^{1}$ This is no mean feat for an institution that has been in Fiji for 141 years, and is valued at F\$ 140 million, according to a columnist with The Australian, owned by News Limited (Day, 2010). Bainimarama denied that The Fiji Times was being 'targeted' for refusing to cooperate with his government, although in an interview with Radio Australia, he accused the newspaper of being biased against his government (Frank, uncensored, 2009). Letters of support for The Fiji Times poured in locally and from abroad. One letter by Reapi Nayacakalou of Nadi reflects the status the newspaper has acquired with many readers:

I will certainly miss this newspaper that has been part of my life for the past four and a half decades. Every bit of it from the first page to the last has been filled with a lot of interesting and educational materials and news items. (Nayacakalou, 2010)

The Fiji Times was given until September 28 to comply with the decree. The sale or closure of the iconic newspaper will be another fateful day in Fiji's history, making 2010 a 'memorable' year for media 'transformation' in Fiji.

\section{Concluding remarks}

The Bainimarama government has succeeded where other Fiji governments failed in introducing a punitive media law. Some see the law as an attempt to cower and control the media, while others see it as a means of improving reporting standards and making media accountable. Fiji may have set the precedence for copycat laws in other island countries where governments are generally suspicious of the media. There are concerns about the effect of excessive legislation and punitive measures on the media's ability to report bad governance, including corruption, which is the bane of some island countries. Developments in Fiji also give rise to questions about the suitability of conventional media approaches and practice in ethnically divided, politically tense Pacific Island nations. The value placed on conflict as a news element in Western journalism can lead to serious consequences when used in fragile, multiethnic societies. The challenge facing Fiji and other Pacific Island governments is how to regulate the media without simultaneously suppressing the freedom of speech. This is an issue that is taking on greater 
significance and needs to be the focus of further research. The Fiji media, on its part, needs to carefully consider its priorities because Fiji has great needs. More than 45 percent of the population lives in poverty. People are paid a pittance for their labour and generations remain caught in the poverty trap. Fiji not only needs a free media, but also a socially responsible media less focused on prominence and conflict, and more committed and devoted to the needs of its people. Fiji needs a media free of political influence and manipulation, and unencumbered by excessive government control and persecution.

\section{Note}

1. On Tuesday, 22 September 2010, after completion of this article, News Ltd officially signed over ownership of The Fiji Times to the Suva-based Motibhai group. Chairman Mahendra Motibhai Patel, who is also the new Fiji Times board chairman, named Australian journalist and executive Dallas Swinstead, a former publisher of The Fiji Times from 1976 to 1980, as new publisher.

\section{References}

Address to the nation of Fiji by Prime Minister Commodore Voreqe Bainimarama following the court of appeal ruling. (2009, April 9). Ministry of information, communications and archives media release.

Bale, Q. (2003). Comments made at the Fiji Editors' Forum on the theme 'Media Freedom, Our Responsibility', Suva. May 7.

Chaudhry, M. (1999). Fiji news media faces crisis of ethics? In Chaudhry and the Fiji Media (pp. 134-146). Pacific Journalism Review, January 2000, 6(1).

Day, M. (2010, July 18). Fiji's dictator mustn't get away with censorship attempt. The Australian. Retrieved on 22 August 2010, from www.theaustralian.com.au/business/media/fijis-dictators-mustnt-get-away-with-censorship-attempt/storye6frg996-1225893671822

Fiji's Chaudhry duels with news media. (1999, November 19). Pacific Media Watch. Retrieved on 31 August 2010, from www.asiapac.org.fj/cafepacific/resources/ aspac/fiji2459.html

Fiji media decree entrenches regime's control. (2010, June 29). The International Federation of Journalists.

Fiji Times, The (1999). The Fiji Times hits back. Republished in Pacific Journalism Review, 6(1):147-153.

Frank, uncensored. (2010, August 3). ABC News. Retrieved on 31 August 2010, from www.abc.net.au/foreign/content/2010/s2968124.htm

Gounder, C. (2007). Fiji 2000: Journalists and the George Speight coup. Pacific Journalism Review, 13(1), p. 140. 
Grynberg, R., L., Munro, D., \& Michael, W. (2002). Crisis: the collapse of the National Bank of Fiji. Suva, Fiji: University of South Pacific Book Centre

Hands off, Fiji's leader tells Australia. (2010, July 7). Fijilive. Retrieved on 4 September 2010, from www.fijilive.com/news_new/index.php/news/show_news/26845

Lal. (2010, June 22). W Holdings Ltd's road to more than $\$ 1$ million from collapsed NBF [Weblog message]. Retrieved from http://webcache.googleusercontent. com/search?q=cache:U_MiR89vECYJ:www.coupfourandahalf.com/2010/06/ bw-holdings-ltds-road-to-more-than.html+national+bank+of+fiji+berenado+vun ibobo+water+under+the+bridge \&cd $=1 \& \mathrm{hl}=$ en $\& \mathrm{ct}=\mathrm{clnk} \& \mathrm{gl}=\mathrm{fj} \& \mathrm{client}=$ firefox-a Media Councils in an unstable political environment. (2004, February 1). Australian Press Council. Retrieved on 31 August 2010, from www.presscouncil.org.au/pcsite/ activities/meetings/asiapac/daryl.html

Media: payback time for Fiji's news critics. (1999, October 29). Asia Pacific Network. Retrieved on 31 August 2010, from www.asiapac.org.fj/cafepacific/resources/aspac/ fiji5.html

Nayacakalou, R. (2010, July 5). Part of my life. Fiji Times Online. Retrieved on 29 August 2010, from www.fijitimes.com/story.aspx?ref=archive\&id=151196

Only military can save Fiji: Bainimarama. (2010, August 4). Sydney Morning Herald. Retrieved on 2 September 2010, from http://news.smh.com.au/breaking-newsnational/only-military-can-save-fiji-bainimarama-20100803-115dc.html

Perfect one day, brutal the next. (2010 July 5). The Australian. Retrieved on 4 September 2010, from www.theaustralian.com.au/news/features/perfect-oneday-brutal-the-next/story-e6frg6z6-1225887754995

PM determined to transform Fiji. (2009, April 16). Ministry of information, communications and archives media release.

PNG prime minister offers Bainimarama tacit support. (2010, April 20). The National Business Review. Retrieved on 31 August 2010, from www.nbr.co.nz/article/pngprime-minister-offers-bainimarama-tacit-support-121774

Raising investment a challenge. (2010, June 13). Fijilive.com. Retrieved on 23 August 2010, from www.fm96.com.fj/iforum/?mod=read\&id=130610e2e6650513dc8bd b5e20ec5ed4ae 53c7d0

Reporters Without Borders. (2010, June 29). Open letter to Prime Minister Frank Bainimarama.

Robie, D. (2004b). The sword of Damocles in the South Pacific: Two regulatory case studies in Fiji, Tonga, Pacific Journalism Review, 10(1), pp. 103-122

Robie, D. (2001). Media: Coup coup land: the press and the putsch in Fiji. Asia-Pacific Media Educator, No 10, pp. 148-162. Retrieved on 28 August 2010, from http://ro.uow.edu.au/apme/voll/iss 10/16/

Robie, D. (2000, July 12). Fiji: Why the media were also Speight's hostages. National Business Review, republished in Asia-Pacific Network. Retrieved on 28 August 2010, from www.asiapac.org.fj/cafepacific/resources/aspac/fiji14.html

Somare Warns PNG Media. (2008, June 6). Solomon Times Online. Retrieved on 5 September 2010, from www.solomontimes.com/news.aspx?nwID=1907 


\section{MEDIA FREEDOM IN OCEANIA}

Singh, S. (2008, August 1). Noose tightens on the media, Fiji Times Online. Retrieved on 31 August 2010, from www.fijitimes.com/story.aspx?id=96632

Singh, S. (2010, August 27). Trouble in Paradise: Punishing Fiji. Asia Society. Retrieved on 2 September 2010, from http://asiasociety.org/policy-politics/ strategic-challenges/intra-asia/trouble-paradise-punishing-fiji

Singh, S., \& Prakash, S. (2008). Storms in the Pacific: The volatile mix of democracy, politics and the media in three island states. In Papoutaski. E. \& H. Sundar (Eds.), South Pacific Islands Communications: Regional perspectives, local issues (pp. 117-132). Singapore: Asian Media Information and Communication.

Statement by Commodore Voreqe Bainimarama, Interim Prime Minister, FijiPacific Islands Forum-Niue (2008, August 18th). Ministry of Information, Communications and Archives media release.

Tonga's Information Minister moves to clamp down on Island's newspapers. (2010, July 14).

Pacific Scoop. (2010, July 14). Tonga's Information Minister moves to clamp down on island's newspaper. Retrieved on 29 August 2010, from http://pacific.scoop. co.nz/2010/07/tongas-information-minister-moves-to-clamp-down-on-islandsnewspapers/

The ups and downs of Fiji politics. (2007, April 30). Fiji Times Online. Retrieved on 31 August 2010, from www.fijitimes.com/story.aspx?ref=archive\&id=61700

We are global: From Fiji, a journalist's stand on censors, bloggers and future of free press expression. (2010, January 7). Global Integrity Commons. Retrieved on 2 September 2010, from http://commons.globalintegrity.org/2010/01/we-areglobal-from-fiji-journalists.html

Shailendra Singh is divisional head of journalism in the School of Media at the University of the South Pacific and a former editor of The Review news magazine. He has researched and written widely on Fiji corruption and governance issues for Inter Press Service and other news media.

singh_sh@usp.ac.fj 